\title{
CONSIDERING THE NEGATIVE IMPACTS OF GLOBALIZATION ON THE SOCIAL SPHERE AND THE ALTERNATIVE OF THE NEW GOVERNANCE
}

\author{
Arvydas Guogis \\ Mykolas Romeris University, \\ Faculty of Politics and Management Institute of Public Administration \\ Valakupių st. 5, LT-10101, Vilnius, Lithuania \\ Telephone +370 (5) 2740611 \\ E-mail: arvydasg@mruni.eu \\ Received on 29 May, 2013; accepted on 30 August, 2013 \\ doi:10.13165/SPV-13-1-5-01
}

\section{Summary}

The aim of the article is to reveal negative impacts of globalization from the social perspective and to present the alternative of the New Governance in an attempt to solve the problem of social exclusion. The article analyses social risk and the syndrome of "speaking winners" and "silent losers", which result from the modern capitalism and affect and distort the social sphere.

The article questions the New Public Management as the means of increasing the efficiency of the administration in the social sphere and analyses the possibilities of the method of "Open Coordination" and the alternative of the New Governance in an attempt to solve social problems.

Keywords: globalization, social policy, "speaking winners", "silent losers", New Governance.

\section{Introduction}

In most cases, globalization serves the needs and meets the expectations of the "winners." However, it has a negative effect on social sphere. Globalization is one of the key causes of the rising social risk, which is related to the establishment of the New economy. In the changing modern world, social risk is becoming a dangerous daily routine for the whole society. Therefore, standards of security and abiding by them should become a more relevant objective of the society than the pace of economic development and the "magical" GDP, which has turned into a kind of a self-pointed indicator. While promoting increase in the rate of return and reckless pursuit of profit, globalization is becoming a threat to society's health, rights, education, sufficient quality of medical care and balanced ecology. It is becoming a threat to social insurance and health services, not only in the narrow sense of social security, protecting traditional social risk groups, but also in the sense of a wider scope of social risk. Social 
insurance and health services, human rights, education and ecology are being removed from the top of the list of national priorities. Under the circumstances of globalization, such order of priority is also encouraged by lower participation of the society: local initiative, selfgovernance and social and public movements are of low political value. This has a clearly negative impact on the political and social systems of the developing countries.

Personal independent voice of an individual has lost its value and is becoming meaningless. Under the circumstances of globalization, uncontrolled situations emerge and not only threaten individuals, but also communities, entire social groups and, finally, national states. On the one hand, social risk is expanding, i.e. global problems affect every single member of the society irrespective of their social status, class or power. On the other hand, globalization affects only particular spheres of life (e.g. alteration of financial markets, military conflicts and increasing oil prices) ${ }^{1}$. At the same time, social risk is being institutionalized through appearance of respective organizations, which view social risk as the principle of individual activity (e.g. investment markets, gambling, sports and insurance). Under the circumstances of globalization, the principle of "boomerang" activities is strengthened (e.g. industrialization and the New economy cause ecological problems and new, the so called "social illnesses", which emerge due to improper lifestyle or profession). Globalization risk factors form an unstable and unpredictable social lifestyle.

\section{Negative Impacts of Globalization and Possible Solutions}

Social policy, social insurance and health services have been constantly developing in national states. The right to social insurance and health services has always been under the competence and jurisdiction of national states. According to historic tradition of Bismarck and Beveridge, social policy is closely related to healthcare policy, which aims at establishing a national healthcare system ${ }^{2}$. Therefore, in the era of globalization, the problem of survival of national states is becoming one of the most relevant issues. It is obvious that globalization diminishes the importance and the scope of competence of national states, and, on the one hand, in this way, the significance of supranational derivatives such as the European Union and NATO increases. On the other hand, with decreased significance of national states, regional derivatives become more important - regionalization processes are being strengthened. Regionalization often stimulates the phenomenon of glocalization. In some cases, entire regions (e.g. in Islamic world, Latin America, Wales and the former USSR) end up as "losers". Taurage's region in Lithuania is an example of such negative regionalization, as its GDP per capita is almost 3 times lower than in Vilnius region ${ }^{3}$. However, regionalization does not always encourage marginalization and glocalization. Sometimes, as it is the case in the European Union, regionalization induces a more rapid development and establishment of social security standards in developing regions and municipalities. However, globalization draws a certain borderline among the Western and non Western civilizations, and in this way, in most cases, it has a negative impact on the latter ones. At the crossroad of the $20^{\text {th }}$ and the $21^{\text {st }}$ centuries, the West comprised only 15 percent of the planet and controlled 70 percent

Guogis, A. Globalizacijos poveikis socialinei apsaugai ir socialinei atskirčiai. Politologija. 2004, 4: 81.

Bitinas, A.; Tartilas, J.; Litvaitienè, J. Socialinés apsaugos teisé. Vilnius: Mykolo Romerio Universitetas, 2011, p. 11-13.

3 Lietuvos statistikos departamentas. Bendrasis vidaus produktas pagal apskritis. 2011 [interactive]. [accessed on dd-mm-yyyy]. <www.stat.gov.lt/lt/news/view/?id=10569>. 
of the world's recourses, production and trade ${ }^{4}$. The West does not only attract the capital, but also it attracts a large flow of immigrants. The process of globalization in the West creates balanced control and sustainability, with the help of which potential competitors might be liquidated by necessity. Under the circumstances of globalization, strong national derivatives are often strengthened and the weak ones are weakened. The only way for the weakly developed countries to survive in the age of the developing information technology and intensive international trade is to establish themselves as independent states within the boundaries of regional integration. Under such circumstances, the strategy of national development must play a crucial role.

The member states of the European Union have high expectations for the method of "Open Coordination". The method of "Open Coordination" seeks to harmonize social policy based on the best practice and its application ("benchmarking"). In the European Union, application of the best practice is being institutionalized in various ways. The method of "Open Coordination" encompasses "local education," "learning from others," "learning with others" and "learning while outrunning failures." The method of "Open Coordination" links the positive aspects of the processes of globalization and Europeization. It can be very effective in the process of implementation of socially engaged social policy and tackling social exclusion in the European Union. The appearance of the method of "Open Coordination" has been greatly affected by globalization processes in the world in the field of private sector and national public administration. Since the end of the last century, a lot of Western countries have used the methods of the private sector in their public administration. These methods were named New Public Management and total quality management, and pursuit of implementing the best practice became the crucial method in the New Public Management. It is obvious that "the pursuit of the best practice" and the method of "Open Coordination" are related by great methodological similarity. That is mainly due to the fact that both methods emerged based on the same reasons - globalization, entrepreneurship and economic and political liberalization of the modern world. However, the method of "Open Coordination" differs from the methods of the private sector in many ways. Due to the peculiarity of public administration, the method of "Open Coordination" can only manifest itself in public institutions. The supranational form of governance (i.e. institutions of the European Union) is necessary for the successful implementation of the method of "Open Coordination". Through application of the method of "Open Coordination", member states maintain the right to choose ways of implementing the objectives set at the level of the EU. The method ensures a process, which is not centralized but is precisely coordinated. This method is being used to integrate a European social model with various models of European Union welfare states.

In order to improve successful implementation of the worldwide objectives in the sphere of social insurance and health services, it is necessary to obtain a broader and more complex understanding of the problems. The appearance of the relevant general context and the public discourse, which is favourable for social insurance and health services, depends on the effort of a great number of people working in the field of business, public administration, culture and science. In order to avoid negative impacts of globalization in social sphere, international, national and local institutions have to deal with a number of urgent issues that fall behind the borderline of the "typical" competence of social insurance and health services. Global collective actions, regional crises management, ensuring global economic stability, environmental protection, development of research and knowledge economy and

Isajev, K. “Obščestvo Riska” v Uslovijach Globalizaciji. Socis. 2001, 12.

Dromantienè, L.; Česnuitytè, V. Europos Sajungos socialiné politika. Vilnius: MRU leidykla, 2011, p. 39. 
the efficiency of international programs of development and support might not only improve the indicators of economic development, but also help achieve the objectives in the sphere of social insurance and health services. It is obvious that in the era of globalization, traditional ways of assessment (that were typical in Welfare states) of economic and social situation should be substituted for non-traditional analysis and non-traditional solutions ${ }^{6}$. In the article "Globalization: Threat or Opportunity?" Paul Streeten presents an analysis, which is a great illustration of a changing public discourse $e^{7}$. According to the article, globalization may not only distinguish itself by negative impact on social processes, but also can contribute to regulation of social situation, insertion of marginal groups and improvement of social cohesion and empowerment if:

1) International Monetary Fund recommendations on "focused application of social programs" oriented towards reduction of social exclusion is adhered to;

2) further tendencies of decentralization are welcomed because they can diminish the significance of the elite and expand the limits of democracy, when the poor and "outcasts" begin to participate in the decision making processes. In this way, the role of various nongovernmental organizations becomes particularly important;

3) the significance of the "shadow economy" is not disregarded, as it can help provide jobs for millions of socially excluded persons and, in this way, grant them opportunities of self-expression and receiving a pay. In the past, the "shadow economy" was considered illegal, "disgusting" and "repellent" and politicians were entirely focused on large scope projects of industrialization and infrastructure. In the era of globalization, the significance of minor low paid job opportunities in "informal sector" is becoming obvious in developing and developed countries.

The first two statements of Paul Streeten should not raise any doubts, whereas the third one seems questionable. Even if Paul Streeten is right about such phenomena being caused by globalization, denying traditional functions of public administration and "transparent economy" could be a dangerous and undesired phenomenon. Due to their negative impact on social sphere and "general health of the society," a lot of applications "urging" and "encouraging" globalization should be met with great caution and reason.

When trying to assess the impact of globalization on the social sphere, it is worthwhile to consider a Marxist approach. Even though traditional society class division is outdated, there exist other forms of stratification that divide the society into "leaders" and "subjects," e.g. "winners" and "losers." Globalization brings profits, better conditions of living and travelling and material and spiritual satisfaction to the "winners." The latter are mostly "speaking classes", who are able to express and defend their interests. However, there also exists a majority of "silent classes," and only a part of it can be ranked as middle classes. A lot of those, who belong to the "silent classes", find themselves in unfavourable conditions and are unable to voice their interests more clearly and defend them. The "speaking classes" are using such weaknesses, for their priority is globalization and new opportunities that come with it ${ }^{8}$. However, globalization often worsens the condition of the "silent classes." As an antipode of globalization, glocalization emerges, which, due to lack of income, illnesses, age, disability, lack of skills, inability to

Guogis, A. Globalizacijos poveikis socialinei apsaugai ir socialinei atskirčiai. Politologija. 2004, 4: 84.

Streeten, P. Globalization: Threat or Opportunity? In: Collins, P. (Ed.). Applying Public Administration in Development: Guideposts to the Future. London: Wiley, 2000, p. 54-55.

8 Guogis, A. Dvi Lietuvos - ne mitas, bet realybè. 2013 [interactive]. [accessed on 12-02-2013]. <www. delfi.lt/news/ringas/lit/aguogis-dvi-lietuvos-ne-mitas-bet-realybe.d?id=60618593>. 
change residential location, etc., in a way "confines" the silent masses. Under the circumstances of globalization, entire classes are marginalized - some continue to make a living solely out of social benefits, others are unable to make a living out of low income and others are forced to live in shelters and "under bridges".

A lot of economists and sociologists have proved that the economic growth that is stimulated by globalization does not automatically eliminate poverty and social exclusion. There is a need for a stronger and "active social policy" or sufficient community support forms, which would not isolate and would not marginalize large masses of citizens. Some Western European countries have strong national social insurance and health services and also various forms of "communitarian" coexistence (such as social partners), most notable of which are trade unions, nongovernmental organizations and other associative organizations. The "silent masses" could only overcome the "speaking masses" if they were well organized and able to voice their interests.

The fact that some members of the "silent class" obtain better education or simply get fortunate and, in this way, join the "speaking elite", does not disprove another fact, according to which the "silent masses" are unable to raise loyal leaders, who would represent them and defend the "silent masses" from the standpoint of labour market and social insurance and health services. Appearance of different controversial political leaders under the open modern sky of Lithuania allows concluding that "the silent" and "the speaking masses" often have very different views towards certain events and processes. This could be compared to two different dishes, which "cannot come into contact" and hardly know or want to know anything about each other. A conclusion could be drawn that globalization and glocalization are two different processes and globalized and glocalized communities have more differences in their own countries than if compared separately to their "equivalents" abroad.

Following the example of Eastern Europe (with only a few exceptions), it is important to apply the method of assessment of "several societies" in each country. In this way, in case of Lithuania, "two Lithuanias" are no longer a myth but a reality, and not taking this into account might result in serious mistakes related to assessment and prognosis. It is not a secret that there was hardly anyone among Lithuanian scientists or journalists, who had predicted Rolandas Paksas' presidency or Vytautas Sustauskas' election to the Seimas. Responsibility should be assumed by the analysts, who are focused on globalization, elite and the "speaking masses" and are completely detached from the reality of Lithuania, the hardships endured by its people and processes of glocalization. The fact that the Lithuanian Labour Party won the third place in the elections of 2012 clearly demonstrates that socially excluded persons can be drawn to the opposite side by offering them "beer and sweets" or bribing them in some other way. Disregarding that, the "silent majority" has threefold negative consequences for the former leaders when there is a need to find nonconstitutional ways to "destroy the new winners," block their access to power or limit them in any other way. In order to satisfy the expectations of the socially excluded persons, it is necessary to not only use political measures initiated by political parties, but also to apply modern administrative methods that would present real and not formal solutions for the "losers." In this way, during the last decades of the $20^{\text {th }}$ century, due to the impact of globalization, the New Public Management was dominating in the Western world and recently, the ideas of the New Governance have been emerging in the world. Such paradigms of management have certain similarities. However, there are many more differences, which are determined by the character of the socially engaged New Governance. It is important to note that for a certain period of time, in order to implement the New Public Management, AngloSaxon countries stimulated their economic growth and induced modernization and efficiency 
of the public sector. However, at the same time, the public sector was reduced. Anglo-Saxon countries spread the spirit of globalization and competition to other places of the world, including Lithuania. However, not all the countries were equally successful at emulating the New Public Management, and some of them, e.g. countries that had been affected by the French culture, plainly ignored it ${ }^{9}$. It is noteworthy that the New Public Management was more efficient at providing decentralized services, first, at the level of municipalities, and then in centralized structures, where it was much less efficient. However, even in the area of service provision (e.g. social services) at the level of municipalities, drawbacks of the New Public Management stood out when trying to create absolute quantitative indicators and failing to meet quality requirements. Not everything, e.g. when providing services to homes, can be measured based on the principle "more services in less time at a lower cost." Sometimes it is important to slow down for the sake of high quality. Consequently, "production" created by scientists cannot be measured only based on the number of published articles, for, most probably, the quality also matters. According to the New Public Management, modernization and improvement of the efficiency of the public sector had to go in line with privatization of the big part of the sector, but, in practice, this did not always serve the purpose. The world's literature is full of examples of failed privatization. On the other hand, the New Public Management used to contradict itself. Instead of realizing the goal of reducing the number of bureaucrats, the New Public Management used to increase it as the whole army of control inspectors was required "to supervise the standards of quantity indicators". At the crossroad of centuries, many people of the Western world began to doubt and criticize the efficiency of the New Public Management. However, the most damage to the New Public Management has been inflicted by the Western economic crisis, which has been going on since 2008. The crisis made the world question social and economic efficiency of the individualized and globalized system of capitalism. The rapid economic growth slowed down and the matters of morality and ethics collapsed (especially among the leadership). The dead end of the capitalism, which was completely out of control, became obvious. Due to the dominance of financial capital over industrial and social capital, the capitalism was clearly under threat. Globalists' fight against national and political identity, as well as ignorance towards other identities, led to absolute moral and cultural crisis. According to the leftist intellectual Berardi (Bifo), in the Western world, capitalism "exhausted itself" and needed a new spur ${ }^{10}$. This is when the New Governance entered the arena of public administration. The New Governance puts emphasis on slightly different aspects, such as openness, transparency, pluralism, democracy, ethics, social justice, social responsibility, eliminating corruption and active role of non-governmental organizations. The New Governance is not only focused on the results, but also on the processes, which, in a way, brings back the age of the traditional hierarchical model of Weber. The objectives of the Welfare state that used to be confined to the New Public Management are arising again, however, this time, in a more modern context of "social quality", where economic-social security, social inclusion, social cohesion and empowerment play an important role. The philosophy of empowerment serves as the basis for the New Public Management, for not only the "empowered" middle class, but also the "empowered" socially excluded groups contribute to sustainable development and balanced economic growth. Active participation of nongovernmental organizations and communities ensures the participation of civil society. It prevents the establishment of oligopolies and monopolies in the

9 Guogis, A. Naujasis viešasis valdymas. Priešingybė ar papildinys Naujajai viešajai vadybai? Savivaldybiu žinios. 2013, 4: 14.

10 Berardi, F. Išeitis iš ekonominès krizès slypi anapus ekonomikos. LUNI, Vilnius [interactive]. [accessed on 29-08-2009]. <www.luni.lt >. 
field of economy, policy and management and in the cultural environment. The significance of the New Public Management has been the focus of many overseas conferences on management and administration. However, not all scholars have a single viewpoint towards it $^{11}$, for the standards and practice of management and administration have not yet been established. It is important to note that compared to the New Public Management, which distinguished itself by clear theoretical principles and specific methods, the New Governance still lacks specifically defined methods of establishment and their application. However, even the most experienced critics or pessimists have no basis for considering the New Governance untimely and irrelevant. It is very important to prevent the New Governance from becoming a mere collection of theoretical prescriptions and to avoid delaying its establishment.

\section{Conclusions}

1. Forming its antipode as glocalization and increasing the social risk, globalization divides the society into "winners" and "losers", and "speaking winners" and "silent losers."

2. Globalization's impact on social sphere is more negative than positive, as it deepens and widens social exclusion.

3. Under the circumstances of globalization, there exists a wide range of methodologies and methods, which are focused on limiting the marginalization of part of the society and finding more effective solutions for social problems.

4. In an attempt to solve social problems during the recent decades, methodologies such as the method of "Open Coordination", the New Public Management and the New Governance have been in the centre of attention.

5. After having implemented the methods of the private sector in public administration, the New Public Management has been criticized for absolutising quantitative indicators, increasing bureaucracy and threatening the public interest.

6. The New Governance has been promoted as an alternative solution to negative social processes and drawbacks of the New Public Management. It stresses openness, transparency, pluralism, democracy, ethics, social justice, social responsibility, eliminating of corruption and active role of non-governmental organizations.

7. Despite its theoretical advantages, the New Governance still lacks practical methods of implementation.

\section{References}

1. Berardi, F. Išeitis iš ekonominès krizès slypi anapus ekonomikos. LUNI, Vilnius [interactive]. [accessed on 29-08-2009]. <www.luni.lt>.

2. Bitinas, A.; Tartilas, J.; Litvaitienè, J. Socialines apsaugos teisè. Vilnius: Mykolo Romerio Universitetas, 2011.

3. Czaputowicz, J. The Influence of Globalisation Upon Public Governance. Viešasis administravimas. 2007, 19.

4. Dromantienè, L.; Česnuitytè, V. Europos Sajungos socialinè politika. Vilnius: MRU leidykla, 2011.

11 Czaputowicz, J. The Influence of Globalization Upon Public Governance. Viešasis administravimas. 2007, 19. 
5. Guogis, A. Dvi Lietuvos - ne mitas, bet realybè. 2013 [interactive]. [accessed on 12-02-2013]. <www.delfi.lt/news/ringas/lit/aguogis-dvi-lietuvos-ne-mitas-betrealybe.d?id $=60618593>$.

6. Guogis, A. Globalizacijos poveikis socialinei apsaugai ir socialinei atskirčiai. Politologija. 2004, 4 .

7. Guogis, A. Naujasis viešasis valdymas. Priešingybė ar papildinys Naujajai viešajai vadybai? Savivaldybiu žinios. 2013, 4.

8. Isajev, K. “Obščestvo Riska" v Uslovijach Globalizaciji. Socis. 2001, 12.

9. Lietuvos statistikos departamentas. Bendrasis vidaus produktas pagal apskritis. 2011 [interactive]. [accessed on dd-mm-yyyy]. <www.stat.gov.lt/lt/news/view/?id=10569>.

10. Streeten, P. Globalization: Threat or Opportunity? In: Collins, P. (Ed.). Applying Public Administration in Development: Guideposts to the Future. London: Wiley, 2000.

\title{
Neigiamas globalizacijos poveikis socialinei aplinkai ir naujojo viešojo valdymo alternatyva
}

\author{
Arvydas Guogis
}

Mykolo Romerio universitetas, Lietuva

\section{Santrauka}

Straipsnyje pristatoma globalizacijos procesu poveikio socialinei sferai analizé. Globalizacija kuria savo antipoda - glokalizacija, taip padalindama pasaulio visuomenes $\dot{c}$ laimètojus ir pralaimètojus. Laimètojai turi balsa ir kalba globalizacijos naudai, pralaimètojai gi yra tylioji visuomenès dalis. Globalizacijos kontekste toks visuomenès stratifikacijos aiškinimas yra tinkamiausias. Globalizacijos neigiami aspektai pirmiausia pasireiškia tuo, kad atotrūkis tarp šiu dvieju grupiu nuolatos didèja sukeldamas vis ryškesnę socialinę atskirtị. Šiai atskirčiai ịveikti egzistuoja nemažai metodologijų, kuriu pagrindinès yra atvirasis koordinavimas, naujoji viešoji vadyba ir naujasis viešasis valdymas. Straipsnyje teigiama, kad naujoji viešoji vadyba diegdama privataus sektoriaus sprendimus viešajame, grisdama veikla kiekybiniu rodikliu duomenimis ir atsisakydama viešojo intereso prielaidos išnaudojo savo potenciala. Naujasis viešasis valdymas yra tapęs naujosios viešosios vadybos alternatyva ta prasme, kad akcentuoja valdžios atvirumą, skaidrumą, pliuralizma, demokratiškumą, etiškuma, socialinị teisinguma ir atsakomybę, kova su korupcija ir aktyvaus vaidmens nevyriausybinèms organizacijoms suteikimą. Tačiau nepaisant teorinio pagrindimo, naujasis viešasis valdymas iki šiol neturi išpletotu praktinio igyvendinimo metodu.

Reikšminiai žodžiai: globalizacija, socialiné politika, „tylieji pralaimètojai“, „kalbantieji laimetojai".

Arvydas Guogis, Mykolas Romeris University, Faculty of Politics and Management, Professor at Institute of Public Administration. Research interests: social security, globalization and social policy, public administration research methodology.

Arvydas Guogis, Mykolo Romerio universiteto Politikos ir vadybos fakulteto Viešojo administravimo instituto profesorius. Mokslinių tyrimų kryptys: socialinè apsauga, globalizacija ir socialine politika, viešojo administravimo tyrimų metodologija. 